\title{
Kernos
}

Revue internationale et pluridisciplinaire de religion grecque antique

1 | 1988

Varia

\section{Divine Personality and Personification}

\section{Bernard C. Dietrich}

URL: http://journals.openedition.org/kernos/77

DOI: $10.4000 /$ kernos.77

ISSN: 2034-7871

\section{Publisher}

Centre international d'étude de la religion grecque antique

Printed version

Date of publication: 1 January 1988

ISSN: 0776-3824

\section{Electronic reference}

Bernard C. Dietrich, « Divine Personality and Personification », Kernos [Online], 1 | 1988, Online since 31 January 2011, connection on 30 April 2019. URL : http://journals.openedition.org/kernos/77 ; DOI : 10.4000/kernos.77 
Kernos, 1(1988), p. 19-28.

\section{DIVINE PERSONALITY AND PERSONIFICATION}

The Greeks thought of their gods as personal beings in human shape. They shared their belief in anthropomorphic gods with other and older cultures, some of which had contributed to Greek religious thought. But their intense personal quality set the Greek gods apart from others and brought them close to their mortal subjects. Eastern gods were also conceived of in the image of man but far removed from his level ${ }^{1}$. The deep gulf between human and divine therefore deprived oriental gods of the most typical and endearing characteristic of the Homeric and Greek Olympians.

The Sumerian gods, for example, despite their human shape, remained vastly superior cosmic powers with only rudimentary personal characteristics. The gods of Egypt, too, were devoid of personality. The names of most major Egyptian deities are particularly interesting in contrast with Greek practice because their meaning is generally transparent. They translate as divine functions rather than personal titles. They describe the common activity, or nature, of a particular god and not his personality. The ithyphallic figure of Min, for example, symbolized the generative force of nature ${ }^{2}$. Amun means 'The Hidden One', that is the invisible god of the air. Chons again translates as 'He Who Passes Through' namely the Moon-god who moves across the sky ${ }^{3}$.

There are worlds of difference between this conception of the gods and that of the highly personal man-oriented figures of classical Greek times. In this respect Greek gods appear to have been exceptional in the Mediterranean world. I doubt whether it is often understood that, with all their dependence on Greek divine myth and tradition, Italian and Roman gods also lacked this

1 E.g. Babylonian Creation Epic, Tablet, VI, $11.5-8, A N E T^{3},(1969)$, p. 68.

2 H. FRANKFORT, Ancient Egyptian Religion, Harper Torch Book, 1961, p. 25-26.

3 S. MORENZ, Ägyptische Religion, Stuttgart, 1960, p. 22. 
peculiarly Greek personal quality. In concept Italy was more closely akin to Egypt than Greece. The divine names also reflected functions which a god performed or symbolized. But for their masculine or feminine gender such titles remained lifeless abstracts. Sometimes a name began as the adjectival description of a function. Parca, for example, the goddess of birth, was formed from the verbal stem * par-, 'to give birth', Genius from *gen-, 'to produce', Aius from the root *ag-, 'to speak', and so on. Even the venerable Ceres, goddess of corn, and the equivalent of the Greek Demeter in myth owed her name to the verbal stem *ker-, 'to grow, to nurture'4. Contrast that etymology with the personal name of Demeter, whatever the meaning of her name 5 . The Romans thought nothing of elevating participial nomina agentis to divine status. Pollens, valens, or gens easily became the gods Pollentia, Valentia or Geneta $^{6}$. They were inanimate forms, all of them, no more than value concepts like Virtus, Victoria, Spes, Honos and the like, all of whom received cults in Roman Italy. It would be wrong to describe such figures as personifications because they lacked a true persona unlike the similar literary creations in Homer and Hesiod. Eris, Hebe, Charis may not have been ancient figures of cult but the two poets endowed them with genealogies and gave them life by fitting them into a family relationship. Eris was amongst Hesiod's primordial forms, mother of Toil, Pain, Hunger and of other similar personifications ${ }^{7}$. She was also sister of Ares like Hebe ${ }^{8}$. They were allegories like Homer's Prayers ${ }^{9}$, or his invention of Charis as Hephaestus' wife because, as one scholiast put it, it is right that Skill, techne, should be together with Grace, charis $^{10}$. Even when

4 G. RADKE, Die Götter Altitaliens, Münster, 1965, p. 37, 59, 85-86, 138 with further modem literature.

5 The old explanation as Ge Meter, 'Mother Earth', is no longer accepted, e.g. W. BURKERT, Griechische Religion der archaischen und klassischen Epoche, Stuttgart, 1977, p. 247-248.

6 = Italian Genita, delvaí gentai on a tablet from Agnone, VETTER, Handb.d. ital. Dial., I, $\mathrm{n}^{\circ} 147$.

7 HES., Theog., 225-232.

8 Il., IV, 441; HES., Theog., 922, sister of Ares and Eileithyia.

$9 \quad$ Il., IX, 502.

10 HOM., Il., XVIII, 382-383. 
Hesiod split Eris into the two figures of Good and Evil Strife as a kind of moral paradigm for men, neither lost her family ties ${ }^{11}$. The institution of a cult to lifeless ideas or values was extremely rare in Greek religion and generally late: The famous altars in Athens to Pity, Shame and Good Repute, Eleos, Aidos, and Pheme were probably not set up before late Hellenistic times ${ }^{12}$.

The opening verse of Pindar's Sixth Nemean Ode speaks of one and the same race of men and gods. Bury explains that the poet wished to insist on the 'ultimate primal unity' of both ${ }^{13}$. Men were drawn into the same family of gods and men ${ }^{14}$. The poet was speaking figuratively of course. He pointed to the close bond between the two worlds without suggesting that a blood relationship existed between Zeus and men ${ }^{15}$, any more than Lactantius intended to be taken literally in his definition of a Christian's pietas as nihil aliud quam parentis agnitio ${ }^{16}$. First and foremost Zeus' title marked out his 'paternal' dominance over all gods and men ${ }^{17}$. But beyond that even metaphorical membership of one family implies that man also shared unity of nature and form with the gods. This oneness could actually be looked at from both sides : either the gods were anthropomorphic or men were theomorphic ${ }^{18}$.

11 HES., Erga, 11-26. For the probable relative chronology of this passage and Theog., 225-232, see M.L. WEST's ed. of the Theogony, Oxford, 1966, p. 44. Cf. his discussion on the genealogy of abstract divine concepts on p. 31-34.

12 H. DÖRRIE, s.v. Göttervorstellung, in Reallexikon für Antike und Christentum, fasc. 89(1981), p. 117.

13 PINDAR, Nem. Odes, J.R. Bury ed., London, 1890, p. 103.

14 E.g. Il., I, 544; Od., I, 28; XX, 201.

15 Ed. DES PLACES, Syngeneia, Paris, 1964, p. 21; C. COLPE, Gottessohn, in RassegnAntCl., 89(1981), p. 27-28.

16 LACT., Inst. Div., III, 9.

17 Cf. M.P. NILSSON, Geschichte ${ }^{3}$, I, Munich, 1967, p. 417; BURKERT, Gr. Rel., p. 204-205. For the same reason El has the title of 'Father of Men' in Ugarit.

18 J. ADAM, The Vitality of Platonism and other Essays, Cambridge, 1911, p. 124 : 'Anthropomorphism implies theomorphism'. DES PLACES (Syngeneia, p. 21) suggests that the notion of Zeus the Father gave rise to anthropomorphism. The reverse process seems more likely, however, namely that 'Zeus' fatherhood was only possible in an already established anthropomorphic pantheon. 
It is a question of attitudes. The Judaic Yahwe was also imagined as anthropomorphic. But he was too far removed and divinely spiritual to be represented in physical form. Man was made in His image ${ }^{19}$ and acted as a symbol of his God. Man strove to be righteous and just. In other words, the relationship was Godoriented, God-focal, to coin an ugly anthropological term. The Jewish attitude to Yahwe is paralleled elsewhere, in ancient Persian Zoroastrianism, for example. The righteous king was the earthly symbol and image of Ahura Mazda ${ }^{20}$. The God himself, however, existed without material form and therefore could not be shown ${ }^{21}$. Such eastern beliefs ${ }^{22}$ contrast with Greek, or I should say Homeric, gods who were fashioned in the image of man. Concepts of the gods' moral superiority, or absolute moral standards, which man should seek to equal, complicated but did not fundamentally alter such epic values. In his Protrepticus Aristotle still recognizably preached the same. The formula homo-deus mortalis was clearly based on the ancient notion of the gods' living personality and their oneness with men ${ }^{23}$.

Epic values do, of course, presuppose literary rather than cultic divine figures. Epic heroes were special men : they lived in the past, were better, stronger and larger than mortals of existing generations ${ }^{24}$. Also they were closer to, and more familiar with, the gods, meeting with them and sometimes even sharing a common table with them 25 . The easy perioche, or communication, then between heroes and gods in the Homeric tradition belonged to a legendary past and not to a realistic present ${ }^{26}$. It would not be

19 Gen., 1, 26-27; 9, 6; Testament of Naphtal, 5, 2; Wisdom of Solomon, 2, 23. Cf. A. HULTGARD, Man as Symbol of God, in Religious Symbols and their Functions, ed. H. BIEZAIS, Proc. Symp. on Rel. Symbols \& their Funct. (Abo 28th-30th Aug. 1978), Uppsala, 1979, p. 110-116.

20 Cf. PLUT., Vit. Them., 27.

21 See HULTGARD, op. cit., p. 114-115.

22 For the confusion in the relationship between man and god in Babylonian religion see H. RINGGREN, The Symbolism of Mesopotamian Cult Images, in ProcSympAbo (supra n. 19), p. 105-109.

23 Fr. 10c Ross = fr. $61 \operatorname{Rose}^{3}$; CIC., De fin., 2, 40; cf. DÖRRIE, in RassegnAntCl, 89(1981), p. 137.

24 Il., V, 304; XII, 383, 449; XX, 287, etc.

25 HES., fr. 82 Rzach; PAUS., VIII, 2, 4-5.

26 See F. PFISTER, s.v. Epiphanie, in RE Suppl. IV(1924), c. 283-284, 291. 
representative of ordinary men who were distinct from the hero with his divine or semi-divine qualities ${ }^{27}$. Nevertheless there is no doubt that the epic, that is the Homeric and Hesiodic, concepts of divinity and divine human relationship directed the accepted religious thought of Greece from archaic times. This is surprising for two reasons in particular. Firstly Homer's heroic figures were generally not the same as the hero of cult. Secondly Homeric epic could hardly be described as religious poetry 28 when compared with Akkadian, Hittite or Ugaritic epics some of which, like the Babylonian Creation Epic, constituted basic elements of cultic ritual and also contributed their ideas to the west ${ }^{29}$.

In a sense the archaic Greek was irreverent enough to allow thoughts of political expediency to govern his notion of the gods. Homer insured that they should be conceived of as universal panHellenic beings and not as localised cult figures. In fact locally bound cult and cult buildings are rarely mentioned in either Iliad or Odyssey. Apollo and Athena alone possessed temples by virtue of their universal nature as city gods. Hence Athena was also worshipped on the acropolis of the enemy city of Troy ${ }^{30}$. Hesiod's view of the gods followed very much along the same lines, albeit for somewhat different reasons. Cult gods were subordinate to general divine figures and concepts ${ }^{31}$. Small wonder that man's view of the gods was also eminently practical : he visualized them like himself in appearance but greater in power.

Everyone is familiar with Xenophanes' criticism of Homer's anthropomorphic gods. According to the epic poets the gods looked, acted and dressed like men ${ }^{32}$. His attack was directed not so much against the fact of anthropomorphism as the arrogance of imagining

27 Dietrich ROLOFF, Gottähnlichkeit, Vergöttlichung und Erhöhung zum seligen Leben, Berlin, 1970, p. 3-101, 151.

28 Cf. the view of P. MAZON, Introduction à l'Iliade, Paris, 1942, p. 294.

29 E.g. Enuma Elish. The epic... was... the most significant expression of the religious literature of Mesopotamia', E.A. SPEISER, in ANET, p. 60.

30 See E. VERMEULE, Götterkult, Göttingen, 1974, p. 105-112; AJA, 79(1975), p. 294, my review of the book.

31 Cf. DÖRRIE, in RassegnAntCl, 89(1981), p. 99-102.

32 X.ENOPHANES, B11; B12; B14. 
the gods in one's own form ${ }^{33}$. Thus the Thracians saw theirs as blond with blue eyes, the Ethiopians black with snub noses ${ }^{34}$. If cattle and horses had hands and could paint with them, they would depict their gods in their own shape ${ }^{35}$. The modern theologian Martin Buber explains the anthropomorphism as man's need to preserve the 'sense of concreteness of the meeting. with God' 36 . He is speaking of the one Christian God, of course, but his views, though no doubt unconsciously, seem tinged with Homeric manoriented values. They envisage the possibility of direct confrontation between god and man in human form. How real this meeting must be imagined is another matter which cannot be precisely answered. Our Christian God, too, for most remains no more than a vague notion derived from the Renaissance conception of divine form modelled on human physical ideals. These incidentally are quite Homeric. The most perfect example and model for later ages has been Michel Angelo's painting of God in the Sistine Chapel in the appearance of a seated bearded man with great physical strength and beauty ${ }^{37}$.

Outside the special cults of Demeter and Dionysus divine epiphanies were quite rare events. In Homer, too, direct physical confrontation between god and hero was uncommon. On almost countless occasions of divine contact with mortal men in epic communication was spiritual more often than actual. Or the description of the encounter is confused, unclear and quite simply impossible in normal physical terms. In those many instances the epiphany had no religious content but revealed itself as an extraordinary poetic device designed to enliven the narrative ${ }^{38}$. Curiously later reports of epiphanies in the historians or in lyric composition were based on the Homeric model and thereby undermine any claims on our credibility. Even the accounts in Acts

33 W. JÄGER, The Theology of the Early Greek Philosophers, Oxford, 1947. p. 42-47.

34 XENOPHANES, B16; B15.

35 XENOPHANES, B15.

36 M. BUBER, Gottesfinsterniss, Zürich, 1953, p. 19.

37 R. HOLTE, Gottessymbol und soziale Struktur, in ProcSympAbo (supra n. 19), p. 4.

38 See my Divine Epiphanies in Homer, in Numen, 30(1983), p. 53-79. 
14 in the New Testament (11-13) of Paul's miraculous healing of the cripple in Lystra still demonstrates the overwhelming force of Homeric tradition in matters of divine visitation. As in our Christian faith the idea of such a meeting was not unreasonable in itself, but very few people had ever experienced one. The main reason for the phantastic form of many Homeric epiphanies is the poet's lack of data regarding divine appearance. Gods change from human to animal or bird to smoke or night. At one moment Athena manifests herself in anthropomorphic shape only to change into a swallow while brandishing her aegis. There were, so to speak, no absolute iconographic norms which could be applied to the Olympians. However, the poet worked on the assumption that their natural shape is human, because that is what he had been taught. The concept of anthropomorphic gods was in fact pre-Homeric and at least as old as the Late Stone Age. But the contribution of the Homeric epic was to impose human standards on the gods not human form.

Homer depicted the gods as human, but as ideal human tỳpes rather than as a palpable physical presence which ordinary men must expect to see in their everyday lives. The distinction is important if one is not to misunderstand Herodotus' much quoted remark that Homer and Hesiod describe the gods' shape or form ${ }^{39}$. The Homeric eidos of the gods established the criteria for sculptors of divine images in the archaic age which consequently were equally idealized. But the Homeric Olympians lacked special individual characteristics beyond their superlative strength, size, beauty, etc. Epithets like dark-haired Poseidon, grey-eyed Athena, cow-eyed or white-armed Hera, no doubt reflected survivals from the past when the deity's power manifested itself in theriomorphic or some other form ${ }^{40}$. But for epic purposes such descriptions rarely carried any special significance beyond their poetic adornment ${ }^{41}$. The Homeric poets did, however, in this way create a vocabulary of divine attributes which signalled areas of special functions for individual gods and also made them instantly recognizable. The painter gladly

39 HDT, II, 53.

40 M.P. NILSSON, MinMycRel ${ }^{2}$, p. 501; G.S. KIRK, The Songs of Homer, Cambridge, 1962, p. 35, 116; cf. BURKERT, Gr. Rel., p. 197.

41 E. SIMON, Die Götter der Griechen 2, Munich, 1980, p. 7. 
accepted this new convention and depicted Athena with her aegis, Hermes with staff and winged sandals, Apollo with bow and lyre, Zeus brandishing the thunderbolt, and so on ${ }^{42}$. The sculptor, too, followed the same precedent when modelling cult statues for sanctuary and temple. Thus the finished product presented something new and to some extent artificial in religion along the lines of the mechanics and form of epiphanies.

The older 'idealised' forms were fast becoming personal figures. Homer also first defined their separate functions and mythology, for their 'Sagenbild' had largely been created for them by epic ${ }^{43}$. The progressive 'personification' of the Olympians is particurlarly well illustrated by their names which no longer described the function or general characteristic of a deity. Some minor figures like Helios and Hestia always retained their obvious significance as god of Sun and goddess of the Hearth. But the names of the major gods were etymologically obscure ${ }^{44}$, sometimes non-Greek or even non IndoEuropean. Even the patently Indo-European figure Zeus had become a 'person' to the classical Greek and was no longer identified with the Sky-god. The Greek practice does not fit into the normal, etymologically transparent, categories of divine nomenclature according to function, invocatory title ${ }^{45}$, locality, or simply the predicative address of 'god'. The Greek went one step further. For him Zeus was a personal experience not the personification of a natural phenomenon. When it rained, he tautologically said, Zeus hyei. It is impossible to determine whether the personal evolved from the impersonal concept ${ }^{46}$. This was Usener's principle that personal gods were the result of a quirkish linguistic development ${ }^{47}$. But if, as seems certain, the Greeks were unaware of the ancient and

42 BURKERT, Gr. Rel., p. 198; cf. F. CHAPOUTHIER, in La notion du divin depuis Homère jusqu'à Platon, Genève, 1952 (Fondation Hardt, 1), p. 85.

43 See K. SCHEFOLD, Myth and Legend in Greek Art, London, 1966, passim, and K. FITTSCHEN, Untersuchungen zum Beginn der Sagendarstellungen bei den Griechen, Berlin, 1969, passim; BURKERT, Gr. Rel., p. 197.

44 BURKERT, Gr. Rel., p. 282-283.

45 B.C. DIETRICH, The Origins of Greek Religion, Berlin, 1974, p. 189; RhM, 121(1978), p. 17.

46 C. KERENYI, Zeus and Hera, transl. C. Holme, London, 1975, p. 10.

47 H. USENER, Götternamen, Bonn, 1896, p. 316 : 'die Bedingung für die Entstehung persönlicher Götter ist ein sprachgeschichtlicher Vorgang'. 
widely differing origins of their 'borrowed' gods, they may well have missed out on the first step of this evolutionary ladder.

Greek divine etymologising generally followed the reverse order from personal name to nomen agentis. Their ears were sensitive to possible concealed meanings in what were ultimately non-Greek divine names. Cassandra in the Agamemnon of Aeschylus called the god Apollo her destroyer, apollon emos ${ }^{48}$. The function is familiar enough from Apollo's past as destroyer and bringer of the plague. But to Cassandra the god was a very personal figure ${ }^{49}$. However, Cassandra's theological pun conceals a fairly intractable problem. If Homer assigned to the gods their functions ${ }^{50}$, when did their names first become known and linked with their cults as we know them in the Greek world ? Chronologically these were two distinct events, because the association of an Olympian name with one particular cult, even his or her oldest Greek cult, was generally much later than the origin of the name itself. In Cyprus, for example, Aphrodite's name had become firmly established by the 8th century B.C., because both Homer and Hesiod connected her with the island. However, her name replaced the older title of Wanassa, or Queen, much later in Paphos. The change came perhaps as late as the 5th century B.C. when Cimon's campaign spread Athenian influence across Cyprus ${ }^{51}$. Aphrodite was of eastern descent but had already been subject to Greek epic influence when she lent her name to the cult goddess in Paphos and elsewhere on the island.

However, Homer did not reflect the spread and nature of archaic cults with their particular deities. There was little contact in epic with the varied historical past of individual gods. The god had no regard for history or politics. So his Olympian pantheon, which became common coinage in the polis, in a sense existed in an historical vacuum. The nature of these Olympians was governed by literary

48 AESCH., Eum., 1081. L.R. PALMER suggests that the form of the name (Apollon) arose through the influence of apollumi, (Mycenaean Religion : the theological choices, in Colloquium Nürnberg 1981, p. 361).

49 All etymologies are unsatisfactory including BURKERT, Gr. Rel., p. 227.

50 HDT., II, 53.

51 S.T. PARKER, Cimon's Expedition to Cyprus, in AJP, 97(1976), p. 30-38; C. BENNETT, The Cults of the Ancient Greek Cypriotes, Diss. Univ. of Pennsylvania, 1980, p. 319. 
criteria and revolved about their proximity to man. Their functions arose from myth and from their duties as community deities. The Homeric contribution therefore was intensely personal. In this context the creation of one divine power from another like Athena from the head of Zeus, or Hephaestus and Ares from Hera is unusual and wayward. It was only subsequent to epic, I believe, that the Greek worshipper saw his god as a person in the true anthropomorphic sense as 'man' or 'woman', so to speak, and not as sexless numinous power. Obviously only then could myths like Zeus' seduction by Hera or the adulterous union of Ares and Aphrodite become amusing as well as meaningful.

Department of Classics

Bernard C. DIETRICH

Hugh Owen Building

The University College of Wales

ABERYSTWYTH

Dyfed SY23 3DY

England 